\title{
NOS BASTIDORES DOS CIEPS: ENTREVISTA COM SILAS AYRES, ASSESSOR DE MARIA YEDDA LINHARES NA SME-RJ (1983-1986)
}

\author{
Sheila Cristina Monteiro Matos ${ }^{1}$ \\ lattes.cnpq.br/8248352711963216
}

No dia em que assumiu o Governo do Estado do Rio de Janeiro, em 1983, Leonel Brizola nomeou a Comissão Coordenadora de Educação e Cultura, confiando sua presidência a Darcy Ribeiro. A comissão era composta pelas secretárias de educação do estado e do município do Rio de Janeiro, respectivamente Yara Vargas e Maria Yedda Linhares, juntamente com o reitor da Universidade do Estado do Rio de Janeiro (UERJ). A atribuição principal dessa comissão era formular a política para o setor educacional e funcionou como órgão diretor do I Programa Especial de Educação (I PEE) (BOMENY, 2008).

Por sua parte, o I PEE (1983-1986) teve como seu principal fazimento a implementação dos Centros Integrados de Educação Pública (CIEPs), mais relevante experiência de escola de tempo integral na educação pública brasileira. Delimitando para o contexto municipal, deve ressaltar que, inicialmente, Maria Yedda², acadêmica por excelência, recusou o convite, afirmando: "Darcy [Ribeiro], [eu] não sei nada de educação de primeiro grau” (LINHARES apud CENTRO DE REFERÊNCIA DA EDUCAÇÃO PÚBLICA, 2007, p. 143). Mas o apelo de Brizola foi irrecusável.

\footnotetext{
${ }^{1}$ Doutora em Educação pela Universidade do Estado do Rio de Janeiro (Brasil). Docente da Prefeitura de Duque de Caxias. Contato: sheilammatos@uol.com.br.

${ }^{2} \mathrm{Na}$ concepção de Faria (apud MIGLIEVICH-RIBEIRO; NOLASCO-SILVA, 2014, p. 226): "[...] o que seria do Rio de Janeiro se não fosse a construção dos 527 CIEPs? E não foram apenas 527 CIEPs [...] A Maria Yedda, quando saiu do governo, deixou todo esse levantamento. Daí a grande importância de estudar a gestão da Maria Yedda na SME do Rio de Janeiro, porque eu afirmaria que a Maria Yedda foi a melhor secretária que o Estado e a capital do Rio de janeiro já tiveram. Montou uma equipe de alto nível e fez a desestruturação do que a ditadura havia feito.
} 
O Partido Democrático Trabalhista (PDT) também mobilizou uma equipe competente. A equipe de assessoria se pautou numa diversidade cujas origens estavam associadas à militância política e ao mundo acadêmico, bem como às instâncias sindicais. Entre os assessores, destacase o professor Silas Ayres de Mattos, que foi assessor especial e chefe de gabinete de Maria Yedda.

Nessa moldura, esta entrevista teve por finalidade colher subsídios para análise dos projetos político-pedagógicos em disputa no I PEE, objetivando referências sobre as relações entre as práticas pedagógicas e o pensamento educacional propagado entre os educadores na década de 1980. O trabalho tem cunho memorialístico, buscando inferências de ações e pensamentos que fizeram e fazem parte do tempo histórico.

Sheila Matos (SM): Vamos começar perguntando sobre a sua convivência com a professora Maria Yedda. Como você a conheceu?

Silas Ayres (SA): Eu conheci a professora Maria Yedda de uma forma muito estranha. Na verdade, eu conhecia de nome a professora Maria Yedda, por causa da época da ditadura, do ano de 1968, das manifestações, ocasiões em que a professora já tinha tido uma participação forte. Mas eu não conhecia pessoalmente. Nessa época, eu era do PDT, tinha sido candidato a vereador e tinha combinado, depois das eleições (eu não fui eleito), que eu ia trabalhar com o deputado Afonso Celso, que tinha sido eleito pela Assembleia Legislativa.

Eu não era professor do município. Era professor da rede particular, vinculado ao Sindicato dos Professores. Eu não tinha vínculo com o ensino público. Um dia recebi um telefonema do chefe de gabinete do professor Darcy, Paulo Bessa, dizendo que precisava urgente conversar comigo, pedindo para que eu passasse lá na Secretaria, que era na Avenida Senador Dantas. Fui à Secretaria de Cultura. Chegando lá, a secretária disse: -“Olha, espera um pouquinho que o professor está saindo”. Ele logo saiu e falou: -"Silas, vem comigo”. Descemos, pegamos o carro oficial dele e ele pediu para o motorista tocar para a Prefeitura do Rio de Janeiro. E falou: -"Estou querendo conversar contigo porque eu quero que vo- 
cê conheça uma pessoa, a professora Maria Yedda. Você a conhece?”. "Conheço de nome". -"Pois é, quero te apresentar. É a secretária municipal de educação. O professor Darcy a colocou na Secretaria Municipal de Educação, e são amigos. Ele está querendo trocar o projeto do CIEP. Ela é uma pessoa de confiança dele, e quer conversar contigo. Vamos lá conversar com ela".

Fiquei meio curioso: -“Mas conversar o quê?”. -"Vamos lá ver”. Quando cheguei, a professora Maria Yedda, muito espontaneamente, disse: -“Professor, eu preciso do senhor". -“Mas em que, professora?”, perguntei. Ela respondeu: -"Eu quero que você venha para cá, para minha secretaria, trabalhar comigo, porque o Paulo Bessa disse que você conhece todo o PDT, que tem uma atuação política, que conhece todos esses partidos políticos. Estou aqui como secretária e estou recebendo uma demanda grande dos políticos. Chegam aqui vereadores, deputados estaduais e deputados federais. Eu nem sei de que partidos eles são, o que representam, se são boas pessoas, se não são. Está havendo muita pressão e eu gostaria que você ficasse aqui comigo".

Eu respondi, - "Mas não posso, professora, porque eu já acertei de trabalhar com Afonso Celso e não posso trabalhar com a senhora”. Ela disse: “-Não!". Tem um detalhe. Na verdade, eu era do PDT, mas fazia parte de uma organização comunista clandestina, como havia muitas naquela época. Era um racha do Partidão, para apoiar Leonel Brizola. O Partidão estava apoiando o Miro Teixeira.

Tudo era definido coletivamente e tinham definido que eu ia trabalhar com o deputado estadual. Por isso que eu falei: -"Não posso, professora”. Ela disse: -“Não, mas eu vou ligar para o Afonso Celso, que é meu amigo". Mandou ligar para ele, explicou a situação e, para minha surpresa, Afonso Celso disse: -"Tudo bem, professora. A senhora pode ficar um tempo com ele, não tem problema nenhum". Eu fiquei surpreso, ela disse, -"Viu Silas? Ele disse que você pode ficar aqui um tempo. É um troço pequeno”. Eu voltei, falei com os companheiros, e eles: -“Ah, Silas! Agora ficou uma situação complicada. O deputado disse que sim. Você fica lá um tempo, depois volta aqui para trabalhar”. Então fiquei lá. 
Fui trabalhar com a professora Maria Yedda numa situação muito esdrúxula, porque eu não era nomeado em nada, nem queria ser nomeado. Ela me levava como assessor parlamentar dela, coisa que não existia na estrutura da Secretaria, e de nenhuma outra. Era muito estranho. Levou todo o corpo de funcionários a achar que aquilo era muito estranho, porque ela me levava como se eu fosse um assessor dela, mas que não tivesse nenhum vínculo com a burocracia. Até o dia que ela disse: -"Silas, eu tenho que te nomear pelo menos para alguma coisa, para que justifique eu te apresentar como meu assessor”. Então ela me nomeou. Não lembro se foi DAS6 ou DAI, ou alguma coisa assim. E passou a me apresentar como assessor dela. Não mais como assessor parlamentar, porque isso não existia.

E foi interessante. Fui para ficar por pouco tempo. Era realmente para ficar pouco tempo. Mas eu conheci a professora Maria Yedda, fiquei mais com a parte do projeto do Darcy Ribeiro, do CIEP, de uma mudança da educação. Realmente, também me apaixonei pela aquela ideia e acabei gostando do trabalho. Fiquei mais tempo, trabalhando com a professora Maria Yedda, como um assessor. Vamos chamar assim, um assessor especial dela. Até o dia em que o chefe de gabinete pediu demissão e ela me nomeou seu chefe de gabinete. Fiquei até mais ou menos 1985, quando pedi para sair, já que as atividades políticas na época exigiam que eu estivesse fora da secretaria. Foi assim que conheci a professora Maria Yedda.

SM: Fale da sua visão sobre a professora Maria Yedda Linhares. Quem foi ela? Quem é ela?

SA: Eu convivi com a professora Maria Yedda desde 1983, quando fui para a Secretaria, e praticamente até o final da sua vida. Mesmo nunca mais tendo trabalhado com ela, desde 1985, acabei ficando muito amigo e, volta e meia, ia à sua casa para conversar, bater papo. De vez em quando, através de amigos, a convidávamos para alguma palestra em universidades. A minha visão sobre a professora Maria Yedda, primeiro, é que ela era uma pessoa muito vinculada a um projeto nacional, a um projeto de país. Era uma pessoa progressista, de esquerda, que foi acusada várias 
vezes de comunista, mesmo nunca sendo. Era uma pessoa realmente comprometida com os interesses do povo brasileiro. Essa é a primeira grande característica da professora.

A outra é a professora de História, reconhecidamente como uma das professoras que mais formou gente nessa área da faculdade. Foi uma grande professora, uma grande historiadora e também uma grande pesquisadora, fosse no campo da história da África ou da história da Reforma Agrária. Outra coisa: é uma pessoa muito comprometida com a questão da educação no Brasil. Isso por sua própria formação intelectual, familiar. Portanto, foi também uma grande educadora. E no meu caso, também uma grande amiga.

Trabalhar com ela foi muito satisfatório, foi muito produtivo. Eu conheci uma pessoa, uma intelectual, que tinha uma forma de trabalhar que, particularmente, me atraiu. A professora era muito dinâmica. Era uma secretária que não ficava no gabinete. Gostava de visitar escolas sem mais nem menos, sem avisar. Nós íamos a algum lugar e se a gente, por acaso, na volta ou na ida, passasse por uma escola, ela dizia: -"Ah, vamos ver aquela escola!”. Ela entrava e conversava com os professores. Aquela forma de trabalhar, um pouco mais informal, que às vezes até chocava algumas pessoas dentro da Secretaria, me atraiu muito. Eu gostava também de trabalhar dessa maneira. Para mim, foi muito satisfatório e muito produtivo trabalhar com ela.

SM: Como era o trabalho da professora Maria Yedda junto ao professor Darcy e Brizola?

SA: Nós éramos da Secretaria Municipal de Educação, que na estrutura, na verdade, era muito mais vinculada ao prefeito. O primeiro prefeito foi o Jamil Haddad e, depois, o prefeito Marcelo Alencar. Todos os dois indicados pelo governador Brizola, já que naquela época ainda não havia eleição direta para prefeito no município do Rio de Janeiro. Então, não tive grande convivência com o governador Brizola. Com o professor Darcy Ribeiro tive mais contato por causa do Programa Especial de Educação, que também a Secretaria Municipal fazia parte. A gente tinha, al- 
gumas vezes, reuniões, conversas e discussões. Particularmente, sobre a relação da professora com o Brizola, não sei muito bem, já que ela era ligada mais ao prefeito.

Quanto ao professor Darcy Ribeiro, ela era sua amiga desde 1930 e tanto. Tinham muitas afinidades, principalmente na área da educação, em cima da questão do Anísio Teixeira. Os dois eram fãs incondicionais do projeto de Anísio Teixeira. O professor Darcy implementou o projeto de Anísio quando secretário de cultura no Rio de Janeiro, vicegovernador e, depois, coordenador do programa do CIEPs.

SM: Como era a relação da professora Yedda com o CEP (Centro Estadual de Professores)? O que era o sindicato na época, e as outras categorias da educação?

SA: A professora tinha uma história. Havia trabalhado com os movimentos sociais. Tanto antes de 1964 como em 1968. Ela respeitava todos esses movimentos, fosse sindical, fosse movimentos de bairro. É lógico que, quando você vai para o governo, essa relação nunca vai ser uma relação tranquila, a não ser que haja uma pelegada. Mas, se não for pelego, a relação entre os movimentos sociais, movimentos sindicais e governo sempre será uma relação tensa. Portanto, era uma relação tensa, mas respeitosa. Ou seja, havia discussão. Me lembro que, no momento em que chegou o orçamento da educação, se não me engano em 1984, a professora teve a ideia de chamar o CEP, a FAMERJ (Federação de Associações de Moradores do Estado do Rio de Janeiro) e a FAPERJ (Fundação de Amparo à Pesquisa do Estado do Rio de Janeiro) para discutirmos o orçamento. O orçamento da Câmara dos Deputados já vinha engessado.

E foi uma discussão interessante. Corretamente, tanto a FAMERJ, que naquela época era o Chico Alencar (não me lembro bem quem era nesse momento), Godofredo pelo CEP, se não me engano, o Irineu pela FAPERJ, eles tiveram uma posição correta. Eles disseram o seguinte: "Vocês são o governo. Vocês vão definir as prioridades. Vocês não podem pedir isso a gente, porque para nós tudo é prioridade. Nós não podemos definir prioridade de governo. Prioridade de governo quem define é o go- 
verno”. Eu falei: -“Mas Godofredo, isso é uma visão muito corporativa sua”. Ele disse: -"Silas, todo movimento social é corporativo. Todo sindicato é corporativo e tem que ser corporativo". Portanto, era uma relação tensa. Houve greves. No entanto, era uma relação extremamente amistosa. Conversávamos com o CEP. Mesmo que houvesse um confronto, mais cedo ou mais tarde, era uma relação respeitosa. Havia diálogo.

\section{SM: Quem a professora Maria Yedda representava enquanto grupo?}

SA: Antes de responder essa pergunta, eu quero lembrar sobre a questão da relação entre o Governo Brizola, a professora Maria Yedda e Darcy Ribeiro com os movimentos sociais. O fato marcante foi a assembleia que houve no cunho municipal, ocasião em que o Brizola foi à assembleia, recebido com bastante animosidade pelo CEP e desconfiança pelos professores. Em duas horas, ele saiu de lá aclamado. Dialogou com os professores e ofereceu tudo o que ele poderia dar naquele momento. Até muito mais do que o Secretaria de Fazenda recomendava. César Maia, que comandava a Secretaria da Fazenda, ficou meio apavorado com o Brizola aceitando a reinvindicação dos professores. Portanto, era uma relação tensa, mas respeitosa. Até porque, na época, o PT (Partido dos Trabalhadores) dominava o Sindicato dos Professores e era ideologicamente, radicalmente, contra a proposta do PDT.

Se ela representava algum grupo? Eu acho que não. Ela podia representar uma ideia de um projeto nacional baseado na libertação do brasileiro através da educação. De um nacionalismo que tinha suas vertentes anti-imperialista, principalmente a norte-americana, apesar dela ter boa relação com os Estados Unidos, onde estudou. Ela representava, talvez, a ideia que havia sido construída pelo antigo ISEB33 (Instituto Su-

\footnotetext{
3 Conforme Saviani (2008), no início da década de 1960, havia uma euforia desenvolvimentista no país, sob a qual se destacavam duas ideologias incompatíveis entre si: a nacional desenvolvimentista, do ISEB; e a da interdependência, que convergia com a da doutrina de segurança nacional, da ESG, sob a tutela de Golbery. O golpe de 1964 consumou a vitória da doutrina da interdependência, que resultou na vinculação da educação aos interesses do mercado e no oneroso legado cujos efeitos afetam a situação social do país até hoje.
} 
perior de Estudos Brasileiros), de um projeto nacional desenvolvimentista.

Como grupo não, porque não me lembro dessa professora ter participado de algum partido. Nem do PDT ela participou, fosse como militante ou dirigente. Como grupo, dentro da universidade, também parece que não. Ela não era, vamos dizer, uma intelectual orgânica no sentido de falar como determinado grupo, uma ideia de um grupo. Por outro lado, ela também não era uma intelectual tradicional, na medida em que ela só queria ver as suas ideias vinculadas a um projeto nacional, independentemente de partidos ou de grupos corporativos na universidade. Essa é a minha impressão.

SM: Você tem conhecimento sobre o núcleo familiar de Yedda? Fale-me um pouco sobre.

SA: Olha, não cheguei a ter tanta intimidade sobre a questão familiar. O que eu conhecia era pouco. Seus filhos, Zeca e Maria Teresa, tiveram participações muito ativas no movimento de 1968 e, depois, foram para o exterior. Com o Zeca, depois, a gente chegou a trabalhar em alguns projetos, já que ele era um grande e excelente fotógrafo, que trabalhava na Prefeitura do Rio de Janeiro. A Maria Tereza eu conheci menos. Do marido dela também não posso falar muito. Eu a achava uma pessoa muito centrada e que, às vezes, em algumas discussões na casa da Maria Yedda, ele dizia: -“Menos gente, menos gente”. Era uma pessoa centrada.

Há os filhos intelectuais da Maria Yedda: o Francisco Carlos Teixeira da Silva que, ela admirava muito; e o Afonso Carlos Marques dos Santos, todos os dois professores de História. O Afonso chegou a trabalhar com ela na época, dirigindo o Departamento Geral de Cultura, na Secretaria Municipal. E o Francisco Carlos foi chefe de gabinete. Eram pessoas jovens, na época, que ela admirava muito intelectualmente. É por isso que eu chamei de filhos adotivos intelectuais da Maria Yedda.

SM: Quais foram os atos e fatos que mais representavam o pensamento de Maria Yedda na sua gestão na Secretaria Municipal de Educação? 
SA: Ela era muito mais vinculada a um pensamento na área de educação, à questão do Anísio Teixeira, à ideia de uma escola que Anísio Teixeira tentou implementar na década de 1930 e que o getulismo, na época, cortou pela raiz, até pela pressão da Igreja Católica. O projeto de Anísio ficou em suspenso até o professor Darcy Ribeiro implantar os CIEPs no Rio de Janeiro. Essa ideia de uma educação integral, de escola de tempo também integral, era novidade em 1983. Muitos aplaudiram, mas muitos resistiram. Particularmente, duas forças razoáveis. Uma muito forte, que era a Rede Globo, que bombardeou as ideias do CIEPs. E uma outra, mais fraca, mas que tinha certa importância nos movimentos sindicais, era o PT.

Especificamente, a professora deu ênfase à alfabetização. Inclusive tentou remunerar melhor o professor alfabetizador, porque ela achava que uma criança bem alfabetizada abriria caminho para o restante na área da educação. Ela tentou isso, mas a burocracia depois vetou. A professora teve como vitória a questão dos Estudos Sociais voltarem a ser as matérias de História e Geografia. Outra coisa muito importante era a questão da democratização da escola. Na sua gestão foram formados conselhos de escolas. Comunidades com participação de pais, professores, substituindo as antigas associações de pais, e a volta dos grêmios estudantis que começam a ser reabertos.

Não menos importante foi a aprovação da eleição para diretores, que, na verdade, foi um projeto da Secretaria Municipal de Educação, com o apoio do vereador Aloísio de Oliveira, que era do PDT. A pressão sobre as nomeações dos diretores de escola era muito grande, tanto pelo partido da situação, quanto da oposição. Todos queriam se intrometer na questão de direções de escola com visões arbitrárias. Nós achamos, entretanto, que a melhor solução era entregar aos professores, aos pais e aos alunos a decisão de quem seria o diretor. Lógico que isso tinha muita resistência e críticas. -"Vocês vão levar para dentro da escola a politicagem que existe já na sociedade. Vai ter professor comprando voto, etc.”.

A gente sabia disso, mas avaliamos que na maioria das escolas haveria eleições honestas. Eleições em que os pais, professores e alunos po- 
deriam escolher os seus representantes. Combinamos com o Aloísio de Oliveira, fizemos uma minuta, e o vereador apresentou. E virou lei. Infelizmente, César Maia, Conde, e todo esse pessoal, de alguma forma, não deixou essa escolha ser tão livre. Foi introduzido algum tipo de seleção para quem seria diretor. A única coisa que exigíamos, que era até uma questão de lei, era que ou o diretor tivesse o curso de administração escolar ou que ele tivesse larga experiência, conhecimento da matéria. Então ele podia se candidatar. Eu quero refrisar que a questão da alfabetização e do ensino mais generalista foram as grandes contribuições de Maria Yedda na sua gestão.

SM: O primeiro Programa Especial de Educação se concretizou por meio da articulação de Darcy e Maria Yedda. Como você relataria o contexto pedagógico e político da época, sinalizando o movimento das categorias educacionais prós e contra esse projeto?

SA: A questão do primeiro Programa Especial da Educação, sem dúvida alguma, é do professor Darcy Ribeiro, o grande responsável. Eu me lembro do grupo do Movimento de Educação do PDT que foi levar reinvindicações. Um programa que nós construímos antes da posse do Brizola. Fomos à casa Darcy Ribeiro. O vereador Amir Amed era professor de História e apresentou todo o nosso projeto. E, depois de 20 minutos de falação do vereador, Darcy o interrompeu, dizendo o seguinte: "mas vocês não falam de crianças, vocês só falam de professores, da estrutura da escola. Até agora você não falou das crianças e eu quero falar das crianças”. Darcy passou a falar sobre o que ele imaginava, o que deveria ser a educação, sobre a ideia dos CIEPs.

Todos ficaram de boca aberta. A visão do Movimento de Educação do PDT era conjuntural de uma época em que havia a Lei 5.692, sobre a qual as oposições ao regime militar achavam que a lei era um produto de uma visão de formuladores tecnocratas, que queriam vigiar, controlar a escola através de novos instrumentos, como supervisores educacionais, orientadores e administradores escolares. Era uma visão generalizada de oposição à ditadura militar, de que a Lei 5.692 precisava ser abolida. Eu 
acho que a lei 5.692 tinha muita coisa boa que, infelizmente, a gente acabou jogando fora junto com todo o restante, que era ruim. Mas o contexto era esse, de uma grande oposição à lei 5.692 e, por outro lado, uma visão muito corporativa.

O Darcy Ribeiro e Maria Yedda (já que também tinha a mesma visão de escola) quebram com isso. Maria Yedda foi uma grande auxiliar no I PEE. Isso não quer dizer que ela não tivesse divergências aqui ou acolá sobre o primeiro Programa Especial, principalmente na forma de gestão. Era problemático, porque havia a Secretaria Estadual de Educação, que administrava o I PEE na área do Estado do Rio de Janeiro, e também havia a Secretaria Municipal de Educação, que administrava o Programa aqui no município. Entretanto, havia uma outra secretaria, que era a Secretaria Especial de Educação, acima das duas. Todo mundo que conhece a burocracia de um governo sabe que isso daria muito problema. Deu muito problema, sem dúvida alguma: choques, ciúmes, inveja, enfim, todos os defeitos humanos apareciam naquilo ali. Mas, do ponto de vista da contextualização da época, o Primeiro Programa Especial de Educação foi muito importante porque mexeu com a escola do Rio de Janeiro. Às vezes até com muita incompreensão. Porque, como o CIEP era uma escola honesta, como o CIEP não queria os supervisores, os pedagogos lá dentro, gerou uma série de incompreensões.

Houve muita resistência da parte do professorado, das escolas que eu chamo de tradicionais. Talvez seria mais politicamente correto, ao invés de jogar esse pessoal para oposição, tê-los atraído para um projeto único. Ter discutido melhor com eles. A outra coisa é que os sindicatos eram contra também, por várias razões, particularmente ideológicas. $\mathrm{O}$ PT achava que o CIEP era uma escola para engordar criancinha. Era para dar comida. Enfim, houve muita resistência também. Mas, no contexto geral, a ideia do Darcy Ribeiro era uma ideia revolucionária. E como toda ideia revolucionária, tinha muita oposição e também muita, mas muita adesão. $\mathrm{E}$ era interessante que as adesões eram de uma forma muito emocional. As pessoas se apaixonavam pela ideia, se jogavam tanto nas escolas como nos grupos de treinamento. Era uma adesão muito emotiva, muito passional, mas também racional. 
SM: Você poderia me falar sobre o contexto do chaguismo 4 e do brizolismo?

SA: Essa pergunta é interessante. Era uma conjuntura complexa. No Rio de Janeiro, as forças de oposição à ditadura, chamadas de Chaguismo, eram o grupo vinculado ao Chagas Freitas, governador do Estado do Rio de Janeiro. Um político tradicional que, através do fisiologismo e do populismo mais barato, conseguiu ter muita força no antigo estado da Guanabara. Entretanto, no resto do Rio de Janeiro, durante algum tempo, o amaralismo era um contraponto ao chaguismo. Amaral Peixoto tinha sido interventor na época do Getúlio Vargas. Tinha uma ligação forte com o getulismo. Ele era casado com a filha de Getúlio Vargas, Alzirinha. Então, durante algum tempo, o amaralismo, na época da ditadura, acolheu as forças de esquerda do antigo Estado do Rio de Janeiro. Mas, com a fusão do Estado do Rio de Janeiro com o estado da Guanabara, o chaguismo foi ganhando muita força e se tornou o braço direito da ditadura. Toda a repressão estava vinculada aos órgãos de segurança. Por sua vez, a força de esquerda agia violentamente contra o chaguismo.

Em 1982, o chaguismo lançou o seu candidato, Miro Teixeira, que era deputado federal. O jovem Miro, percebendo que o mundo estava mudando, começou a ter ideias inovadoras e chamou, para sua própria e principal assessoria na disputa eleitoral, pessoas vinculadas ao Partido Comunista Brasileiro, ao Partido Comunista do Brasil (PC do B) e ao Movimento Revolucionário 8 de outubro (MR8). Enfim, pessoas de esquerda que resolvem apoiá-lo em cima de uma estratégia que era uma aliança contra a ditadura. Era um grande arco de aliança contra a ditadura. Isso levou a um problema dentro dos partidos comunistas. Muitos racharam com isso, asseverando que era impossível apoiar o chaguismo, fosse com o Miro dando oportunidade à esquerda ou não. Na verdade, isso seria

\footnotetext{
4 Refere-se à influência de Chagas Freitas na política do Estado do Rio de Janeiro (1979-1983), governador que antecedeu Leonel Brizola. Imbuídos pela lógica Chaguista, ainda permaneciam algumas manobras que, por meio do uso da "máquina política”, utilizavam práticas antidemocráticas e clientelistas (FARIA, 2011).
} 
uma traição, em razão das lutas que foram travadas contra o chaguismo. Houve muito racha. No meu caso, eu rachei com o PCB e fui para o PDT.

$\mathrm{Na}$ época, havia candidatos que eram vinculados à ditadura diretamente. Sandra Cavalcante era lacerdista, de direita, mas antiditadura, pois o Lacerda havia ficado contra a ditadura no final. Moreira Franco era o candidato explícito da ditadura. Havia ainda o pessoal do PT, um deputado evangélico progressista que tivera muita importância na luta contra a ditadura, e havia o Brizola. O Brizola era o homem que tinha uma história no Rio de Janeiro desde a década de 1960. Veio a ser o deputado federal mais votado no Rio de Janeiro. Brizola voltou do exílio para o Rio de Janeiro logrando galvanizar todas as forças antiditadura. Os progressistas viam nele a continuidade das lutas de 1964. Isso resultou que todo plano traçado, seja da ditadura, seja do chaguismo (Moreira Franco e Miro), fosse por água abaixo, já que na campanha do Brizola houve uma participação popular muito grande, que derrotou todas as forças políticas.

Na área de educação, o chaguismo, responsável pela campanha do Miro [Teixeira], tinha professores progressistas. Pessoas ligadas à esquerda, que tinham uma visão diferente, mas também muito parecida com as propostas do brizolismo. Porém, o que havia de diferença entre essas propostas da educação e esses grupos chaguistas era a importância que o Brizola dava à educação. Brizola tinha uma visão política de que a educação era fundamenta. Ele achava que a criança bem-educada seria uma pessoa que conseguiria lutar pela liberdade em todos os sentidos da palavra. O melhor era que ele tinha o Darcy Ribeiro, que é um grande nome na área da educação brasileira. Nesse sentido, o brizolismo na área de educação tinha um carro-chefe. A prioridade máxima era a educação. Para nós, que éramos professores, isso era muito importante na adesão à campanha do Brizola.

SM: O que você poderia nos falar sobre o Encontro de Mendes5?

\footnotetext{
5 As bases do I PEE foram debatidas no Encontro de Mendes, em 1983, evento que aprofundou as discussões sobre o fracasso da escola pública (CUNHA, 2005).
} 
SA: O Encontro de Mendes foi uma ideia do Darcy em fazer um congresso na área de educação, quase nos moldes das antigas teses dos partidos comunistas, dos seus congressos. Ele e o grupo que o auxiliava redigiram as teses para educação no Rio de Janeiro. A ideia era que todas as escolas discutissem aquelas teses e designassem delegados para se representarem no Congresso de Mendes. Esses delegados saiam da escola, depois iam para suas regiões, até formar um número "x" de delegados, que então discutiriam as teses.

SM: Qual a contribuição de Maria Yedda para a escola de tempo integral? Que educação integral era essa? E os confrontos políticos da época? Será que seriam as escolas de favelas?

SA: A concepção de escola de Maria Yedda, assim como a de Darcy Ribeiro, era baseada na escola de Anísio Teixeira, no seu projeto de educação. A contribuição da Maria Yedda no município do Rio de Janeiro concretizou as ideias de Anísio Teixeira. Isso era uma novidade, porque Anísio tinha feito uma experiência na Bahia, depois começou uma experiência no Rio de Janeiro, em 1935. Essa experiência foi abortada por sua demissão. Depois, nas décadas de 1950 e 1960, ele implementou algumas escolas experimentais em larga escala. $\mathrm{E}$ foi somente através do projeto especial de educação do governo Brizola, com a coordenação do Darcy Ribeiro, que a Maria Yedda concretizou no município do Rio de Janeiro a ideia do Anísio Teixeira.

Quanto à questão do contexto, era uma novidade, apesar de ser um projeto antigo. Nesse ínterim, os setores das elites, fossem na mídia, fossem elites partidárias, fossem elites sindicais, tinham uma certa resistência a esse tipo de projeto. Viram algo perigoso, que faria a cabeça das criancinhas, porque era eleitoral. Havia alguns problemas nesse contexto. Quanto à questão da escola dos pobres, isso foi um marketing negativo. Darcy Ribeiro e Brizola diziam que os CIEPs seriam uma escola honesta, uma boa escola. Uma escola que teria condições de abrigar as crianças, que teria auditório, quadra, casa para crianças de rua. Enfim, diziam que era uma boa escola e que os pobres teriam direito a frequentá-la. O pro- 
blema que, na política ou na propaganda, nem sempre as boas ideias são bem vinculadas.

Nessa questão, a oposição, fosse na mídia ou nos partidos políticos, passaram a dizer que o Darcy estava dizendo que a escola tradicional, a rede, toda era desonesta. Portanto, os professores se sentiram muito chateados com isso. Nós tivemos embates para dizer que não era bem isso com os professores, mas eles diziam: "não, mas foi dito que nós somos uma escola desonesta”. A mesma coisa foi com a questão dos pobres. Nos anos 1990, eu tive uma experiência com a professora Mariléia, que era secretária. Nós fomos a um CIEP fazer uma reunião com os pais de alunos na área de Irajá. Os pais não queriam ingressar seus filhos no CIEP e, uma das razões que eles disseram, era porque eles não eram pobres. Esse marketing, essa marca que ficou como o CIEP sendo uma escola dos pobres, fez com que a classe média, ou até mesmo o pessoal mais pobre, que eram os trabalhadores, resistissem à ideia dos CIEPs. Isso foi um marketing. Não era uma escola para pobres, era uma escola em que os pobres teriam acesso.

SM: E a concepção de educação integral? Me fale um pouco mais sobre ela, por favor.

SA: A concepção da escola de educação integral é muito mais do que tempo integral. Ficou muito ligada essa história de que a criança entrava às sete horas, fazia um lanche, depois saía às cinco horas, depois de tomar banho e jantar. Isso foi o que a mídia enfatizou. Mas era muito maior. Quem lê o livro preto do CIEPs, quem lê toda a proposta pedagógica, vê que a ideia de uma educação integral era no sentido da pessoa integral, todo ser da pessoa, em suas várias atividades...

SM: Moral, física...

SA: É. Moral e física. Você tinha Educação Física, aula de teatro, Educação Artística, Matemática, Ciências. Era uma educação, do ponto de vista da história do Brasil, que não havia até aquela época. Hoje, até a Globo 
defende essa ideia. Eduardo Paes diz que também defende os CIEPs. Todo mundo elogia Anísio Teixeira. Mas isso demorou a acontecer. Anísio começou na década de 1920 essa discussão e, só hoje, é que realmente essa ideia passou vitoriosa, pelo menos no discurso. Entretanto, o mundo já é outro, até porque a ideia do Anísio Teixeira é de uma escola para uma época industrial, para uma época de um país que estava querendo se desenvolver industrialmente. Era uma escola adequada para aquela época. Hoje, a escola tem que ser outra coisa. O Brasil é muito atrasado. As nossas ideias vêm, tão devagar, que quando elas chegam, às vezes, já passaram da época ideal de implantação.

\section{SM: O que Maria Yedda pensava sobre os pedagogos?}

R: Essa é uma outra coisa que ficou quase como lenda urbana. Vou contextualizar a questão dos pedagogos, a questão dos especialistas. Como eu disse, a lei 5.692 foi elaborada em 1971 e foi promulgada, se não me engano, em 1972. Foi uma lei de diretrizes e bases estabelecida na época da ditadura. Todos que lutavam contra a ditadura viam na lei 5.692 um instrumento da ditadura. E nisso erradamente foi colocado que todos os especialistas de educação, na verdade, seriam meros instrumentos da ditadura. Os administradores escolares estariam ali para transformar a escola em uma coisa eficiente, como hoje se fala, eficaz. Pessoas especializadas em administração. Os supervisores educacionais seriam as pessoas que ficariam responsáveis para impor o tipo de projeto pedagógico que a ditadura queria colocar. Os orientadores educacionais eram meros instrumentos para levar as crianças para se educarem para o trabalho capitalista.

Havia uma ideia violentamente contrária à lei 5.692, e, vamos dizer, um populismo pedagógico. Nós acreditávamos que quem entendia de educação era o professor de sala de aula, e não a burocracia que estava instaurada na Secretaria Municipal, nos DECs (atuais Coordenadorias Regionais de Educação - CRE). Na verdade, se consultarmos a tese de, se não me engano, Guiomar Namo de Mello, em São Paulo, verifica-se que não era nada disso. Os pedagogos eram tão progressistas, ou tão de direi- 
ta, como qualquer cidadão. Na supervisão ou na orientação, todos poderiam ter ideias progressistas, e poderiam ter sido chamados para trabalhar com a secretaria. Foi uma forma errônea o pensamento de que, no CIEPs, não deixaríamos pedagogos entrarem. Que no CIEPs não haveria especialistas, porque tudo seria entregue aos professores de sala de aula. Isso foi um outro marketing negativo.

$\mathrm{Eu}$, particularmente, tive reuniões com supervisores nas quais quase fui massacrado por causa de declarações que eu hoje considero, do ponto de vista político, erradas: tínhamos a visão que todos os especialistas eram meros instrumentos da ditadura. Por outro lado, os especialistas erraram quando se colocavam como verdadeiros revolucionários. Eu me lembro que, uma vez, os orientadores fizeram uma manifestação na Prefeitura e eu vi um cartaz que dizia “orientação é a revolução". Também não era isso. Houve erros de todos os lados, mas, certamente, o maior erro foi do governo, das nossas secretarias, que realmente conseguiram expressar um certo preconceito contra os especialistas. Baseado numa análise, friamente, muito dogmática de que tudo que estava na lei 5.692 era instrumento da ditadura para levar os menininhos felizes para o capitalismo.

SM: Yedda colocou teoricamente a discussão sobre a república por ser historiadora. O que ela pensava sobre um governo efetivamente republicano?

R: É interessante. A professora Maria Yedda teve sua formação fora do Brasil, nos Estados Unidos, quando jovem. Se não me engano, ficou uns dois ou três anos por lá. Entretanto, a influência que ela teve na política é muito mais da República francesa. Ela, pelo que eu vi, era uma entusiasta do republicanismo francês. Ela achava que foi um avanço, principalmente na área da educação, quando a França implantou o ensino laico. Não que isso proibisse as escolas religiosas, talvez até tenham proibido em alguma época. Era uma escola única, administrada pelo Estado, uma escola republicana no sentido laico, que não permitia nenhum tipo de vinculação religiosa. Até hoje vemos, até com os muçulmanos, que há alguns 
problemas sobre isso. Em uma república, a escola precisava ser laica. E a Maria Yedda era uma entusiasta da república. Mas a grande influência, pelo que eu entendi, talvez até pelo tempo também que ela passou exilada na França, foi a dos grandes historiadores e intelectuais franceses. A influência é toda francesa e a ideia de república para ela era muito grata. Mas ela pensava que nós éramos o país do jeitinho, um país dos arranjos, pouco republicano. E eu até acredito que ela estivesse certa, vendo o que está acontecendo nos dias de hoje: há muita pouco república e muito fisiologismo, mal feitos.

SM: Qual foi o legado de Maria Yedda Linhares para a educação fluminense?

SA: O maior legado que a professora Maria Yedda deixou no município do Rio de Janeiro, assim como Darcy chegou ao nível nacional, foi a ideia generosa de educação de Anísio Teixeira. Ela se transformou numa ideia vitoriosa, mesmo que hoje ainda tenham discursos hipócritas. Mas ninguém mais ataca uma escola de educação integral nos dias de hoje. Ninguém tem mais coragem de atacar os CIEPs como uma proposta generosa para o avanço da educação no Rio de Janeiro. Nesse sentido, o maior legado que a Maria Yedda deixou foi esse, no momento em que ela batalhou contra todo o conservadorismo que existia na educação do Rio de Janeiro. Mas também coloco como fundamental, aqui no município do Rio de Janeiro, o fato de que a professora Maria Yedda foi a primeira que colocou o Curso de Alfabetização (CA) como fazendo parte do segmento na alfabetização. Assim, se permitiu que crianças de seis anos, apesar de a lei 5.692 dizer que era aos sete anos, fossem matriculadas no Curso de Alfabetização.

A ideia que ela tentou, e aí se vincula algum tipo de desafio - que ainda não foi vitorioso - , foi a ideia que uma criança bem alfabetizada estaria com os caminhos abertos para todos os desafios da vida. Isso ainda não aconteceu. Ainda não se dá essa importância que a professora Maria Yedda deu ao tentar implementar uma gratificação especial para aqueles professores alfabetizadores, já que ela os considerava professores 
fundamentais na educação do Rio de Janeiro. E, para terminar, a ideia do CIEP, a escola em tempo integral, a democratização da escola, tudo isso foi legado de Maria Yedda, com todos os problemas que podem ocorrer ainda hoje. E, ainda, a questão dos professores, pais e alunos terem direito à gerência da escola, a gestão da educação da escola, tudo isso se deu graças à professora Maria Yedda no município do Rio de Janeiro.

\section{Referências}

BOMENY, H. Salvar pela escola: programa especial de educação. In: FERREIRA, M. M. (org.). A força do povo: Brizola e o Rio de Janeiro. Rio de Janeiro: FGV; ALERJ, 2008, p. 95-127.

CENTRO DE REFERÊNCIA DA EDUCAÇÃO PÚBLICA. Memórias da Educação Pública: depoimentos de secretários de educação. v. 1. 2. ed. Rio de Janeiro: SME/CREP, 2007.

CUNHA, L. A. Educação, estado e democracia no Brasil. São Paulo: Cortêz, 2005 .

FARIA, L. Chaguismo e brizolismo: territorialidades políticas da escola fluminense. Rio de Janeiro: Quartet, 2011.

MIGLIEVICH-RIBEIRO, A.; NOLASCO-SILVA, L. Entrevista com Lia Faria - Profa. do Programa de Pós-Graduação em Educação da UERJ. Simbiótica, n. 6, p. 188-232, 2014.

SAVIANI, D. História das ideias pedagógicas no Brasil. Campinas: Autores Associados, 2008.

Recebido em 29 de março de 2017. Aprovado em 15 de abril de 2017. 